\title{
Phytotoxicity of the Fungicide Metalaxyl and Its Optical Isomers
}

M. Singh, Professor, University of Florida, IFAS, Citrus Research and Education Center, Lake Alfred 33850; W. Mersie, Associate Professor, Virginia State University, Petersburg 23806; and R. H. Brlansky, Professor, University of Florida, IFAS, Citrus Research and Education Center, Lake Alfred

\section{ABSTRACT}

Singh, M., Mersie, W., and Brlansky, R. H. 2003. Phytotoxicity of the fungicide metalaxyl and its optical isomers. Plant Dis. 87:1144-1147.

Metalaxyl is a systemic fungicide commonly used in citrus production to control Phytophthora root rot and foot rot. When applied as a drench, injury was observed on newly planted, young citrus trees. The visual injury symptoms ranged from light- to bright-yellow leaves. It was learned that the commercial formulation of metalaxyl contained various isomers and that these isomers may vary in phytotoxic effects on citrus leaves. The objective of this study was to determine the difference in herbicidal activity between the two optical isomers of metalaxyl on pepper plants and citrus leaves. The phytotoxicity of the fungicide metalaxyl and its optical isomers (CGA76538, $\mathrm{S}^{+}$; CGA76539, $\mathrm{R}^{-}$) was determined using a pepper seedling growth bioassay and by measuring protein synthesis as estimated by the incorporation of ${ }^{14} \mathrm{C}$-leucine by citrus mesophyll cells. The two isomers and metalaxyl differed in their herbicidal activity to pepper plants and citrus cells. Pepper seedlings treated with $\mathrm{R}^{-}$had significantly higher mean fresh weight than plants treated with metalaxyl or $\mathrm{S}^{+}$at $0.1,1.0,10.0$, and $100 \mathrm{ppm}$. Protein synthesis, as measured by the inhibition of ${ }^{14} \mathrm{C}$-leucine incorporation by citrus mesophyll cells, also was inhibited more by metalaxyl and the $\mathrm{S}^{+}$isomer than by the $\mathrm{R}^{-}$isomer. After 30 min of incubation at $100 \mu \mathrm{M}$, the $\mathrm{R}^{-}$isomer inhibited ${ }^{14} \mathrm{C}$-leucine incorporation by $29 \%$, whereas incorporation of ${ }^{14} \mathrm{C}$-leucine in the metalaxyl and the $\mathrm{S}^{+}$isomer treatments was higher (46 and $81 \%$, respectively). Similarly, the highest ${ }^{14} \mathrm{C}$-leucine uptake at $60 \mathrm{~min}$ was obtained by $\mathrm{R}^{-}$at all concentrations. The assays showed that the $\mathrm{R}^{-}$and $\mathrm{S}^{+}$isomers differ in their biological activity as expressed by weight loss of pepper plants and inhibition of protein synthesis and that the $\mathrm{S}^{+}$ isomer is responsible for the phytotoxicity of metalaxyl. The findings in this study show that the phytotoxicity of metalaxyl was due to the presence of the $\mathrm{S}^{+}$optical isomer. Removal of this isomer from metalaxyl has enabled the continued use of this fungicide for control of foot rot and root rot in citrus.

Additional keywords: Capsicum frutescens L., Citrus sinensis L. Osbeck, Ridge pineapple, 'Yolo Wonder' pepper

The systemic fungicide metalaxyl is widely used in citrus production to control root rot and foot rot diseases caused by Phytophthora spp. when applied as a soil drench, a stem paint, or foliar spray $(3,6,7,13,15)$. In young citrus trees, the fungicide usually is applied as a drench or ring treatment and, in Florida, it often is applied as a tank mix with various herbicides. In young field-grown citrus trees, bright yellow foliage with some leaf necrosis was observed following metalaxyl treatments. The yellowing was observed on both young and old leaves. Initially, herbicide injury was suspected; however, the symptoms were not typical of the damage

Corresponding author: R. H. Brlansky E-mail: rhby@lal.ufl.edu

This research was supported by the Florida Agricultural Experiment Station, and approved for publication as Journal Series No. R-02968.

Accepted for publication 30 April 2003.

Publication no. D-2003-0714-01R

(C) 2003 The American Phytopathological Society fungi (11). In these in vitro tests, selected fungi (of the order Peronosporales) were inhibited in the inhibitory concentration $50 \%\left(\mathrm{IC}_{50}\right)$ value range of 0.1 to $0.3 \mathrm{ppm}$ for $\mathrm{R}^{-}$and $100 \mathrm{ppm}$ for the $\mathrm{S}^{+}$isomer.

Metalaxyl is similar in chemical structure to the herbicide metolachlor, which also is a mixture of $\mathrm{R}^{-}$and $\mathrm{S}^{+}$isomers. The $\mathrm{S}^{+}$isomer is more active as a herbicide than the $\mathrm{R}^{-}$and has been selected for commercial production due to its activity on susceptible plants and its efficacy at low rates (16). Metalaxyl was a mixture of both isomers and caused visible herbicide type symptoms in greenhouse tests; therefore, studies were initiated to determine the herbicidal activity of both isomers on citrus leaves and pepper (Capsicum frutescens L.).

The objective of this study was to determine the difference in herbicidal activity between the two optical isomers of metalaxyl on pepper plants and citrus leaves.

\section{MATERIALS AND METHODS}

Pepper growth assay. Pepper plants ('Yolo Wonder') previously were found in preliminary experiments to be highly sensitive to metalaxyl (W. Mersie and M. Singh, unpublished). Pepper seeds were sown (1 $\mathrm{cm}$ deep) in pots filled with vermiculite and germinated in a greenhouse. At the three-leaf stage, the seedlings were removed from the vermiculite, their roots were washed, and fresh weights were measured. The seedlings then were trans-
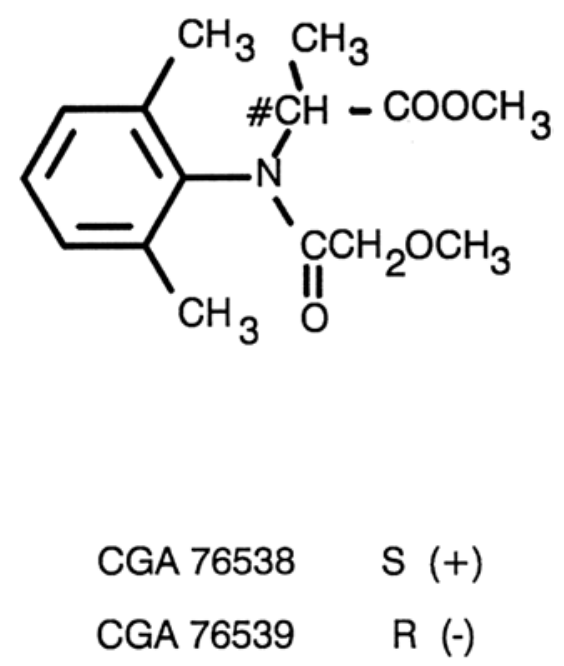

Fig. 1. Metalaxyl and its two isomers (CGA $76538 \mathrm{~S}^{+}$and CGA $76539 \mathrm{R}^{-}$). The asymmetric (\#) carbon in the alkyl side chain. 
ferred to 50-ml Erlenmeyer flasks containing $50 \mathrm{ml}$ of half strength Hoagland and Arnon solution (10) and were grown in a laboratory under $250 \mu \mathrm{E} \mathrm{m} \mathrm{m}^{-2} \mathrm{~s}^{-1}$ photosynthetic photon flux density provided by fluorescence lamps with a 14-h photoperiod at a room temperature of $24 \pm 1^{\circ} \mathrm{C}$.

After $48 \mathrm{~h}$, the solution was changed with a Hoagland and Arnon solution, and metalaxyl or CGA $76538\left(\mathrm{~S}^{+}\right.$isomer) or CGA 76539 ( $\mathrm{R}^{-}$isomer) at 0 (control), 0.1, $1.0,10.0,100.0$, and $250 \mathrm{ppm}$ (wt/vol) were directly added to the solution. Metalaxyl at $250 \mathrm{ppm}$ is equivalent to the recommended field application rate of metalaxyl on citrus. After 7 days, the seedlings were harvested and their fresh weights were determined. Experiments were repeated three times with three replications and the combined data were subjected to analysis of covariance to remove variation in final weight that is associated with initial weight (8). The adjusted means of fresh weight of seedlings were compared with a paired $t$ test.

Citrus cellular assay. Eight-month-old sweet orange seedlings (Ridge Pineapple) were grown from seed in planter flats in a greenhouse with a 14-h photoperiod. The growing medium used was Promix- $\mathrm{BX}^{3}$ (peat:perlite:vermiculite, 3:1:1, vol/vol/vol). The plants were watered daily and fertilized once per week with $1 \%$ Nutrileaf $(\mathrm{N}$ P-K, 20:20:20) solution. The average photosynthetic photon flux density was 250 $\mu \mathrm{E} \cdot \mathrm{m}^{-2} \cdot \mathrm{s}^{-1}$ at plant level. Day and night temperatures were 25 and $26 \pm 2{ }^{\circ} \mathrm{C}$, respectively.

Mature citrus leaves (third or fourth youngest) were detached from the experimental trees, rinsed with distilled water, blotted, deveined, and cut into 1-mm-by-1$\mathrm{cm}$ strips with a razor blade. About $5 \mathrm{~g}$ of leaf tissue then were vacuum infiltrated with $30 \mathrm{ml}$ of infiltration medium $(20 \mathrm{mM}$ MES [2-( $N$-morpholino)ethanesulfonic acid], $\mathrm{pH} 5.8$, with $0.1 \%$ macerase, $2 \%$ pectinase, and $0.3 \%$ potassium dextran sulfate; 9). The leaf tissue was filtered through a $200-\mu \mathrm{m}$ nylon net and the tissue was transferred to a beaker with $30 \mathrm{ml}$ of maceration medium (20 mM MES, pH 5.8, containing $0.2 \%$ pectinase, $2 \%$ cellulose, $0.3 \%$ potassium dextran sulfate, and $0.6 \mathrm{M}$ manitol; 9). The tissue was stirred slowly on a magnetic stirrer for $10 \mathrm{~min}$, the suspension was filtered through the 200- $\mu \mathrm{m}$ nylon net, and the filtrate was discarded. The leaf tissue was transferred to another $30 \mathrm{ml}$ of fresh maceration medium and was stirred for $2 \mathrm{~h}$. The cells released during this period were filtered again through the 200- $\mu \mathrm{m}$ nylon net and washed three times with 10-ml aliquots of incubation medium and centrifuged at $60 \times g$ for $3 \mathrm{~min}$. The pelleted cells were resuspended in incubation medium $(0.5 \mathrm{mM}$ mannitol, $5 \mathrm{mM}$ $\mathrm{KNO}_{3}, 2 \mathrm{mM} \mathrm{Mg}\left(\mathrm{NO}_{3}\right)_{2}, 1 \mathrm{mM} \mathrm{CaCl}{ }_{3}, 50$ $\mathrm{mM}$ HEPES-KOH buffer, $\mathrm{pH}$ 7.8). For chlorophyll determination, three 1-ml sam- ples of the final cell suspension were placed in three 15-ml centrifuge tubes. To each tube, $4 \mathrm{ml}$ of $80 \%$ acetone was added and the tubes were vortexed. The supernatant fluid then was assayed spectrophotometrically for its chlorophyll content according to the methods of Arnon (1). The chlorophyll content of cell preparations used in this study was 15 to $25 \mu \mathrm{g}$ chlorophyll/ml of incubation medium.

${ }^{14} \mathrm{C}$-leucine incorporation into protein of citrus mesophyll was measured after 30 and $60 \mathrm{~min}$ of incubation as described by Hatzios (9). Briefly, $2 \mathrm{ml}$ of the cell preparation and $0.1 \mathrm{ml}$ of $\mathrm{L}-\left[\mathrm{U}-{ }^{14} \mathrm{C}\right]$ leucine (specific activity $290 \mathrm{M} \mathrm{Ci} / \mathrm{m} \mathrm{mol}$ ) containing $0.1 \mu \mathrm{Ci}$ of radioactivity were placed in 50-ml Erlenmeyer flasks. Analytical grades of metalaxyl, CGA $76538\left(\mathrm{~S}^{+}\right.$isomer), and CGA 76539 ( $\mathrm{R}^{-}$isomer) were dissolved in methanol and made up to volume with distilled water so that the final methanol concentration was less than $1 \%$. Concentrations of the metalaxyl and its isomers were $0.1,1.0,10.0$, and $100 \mathrm{ppm}$. Flasks with the assay mixtures (cell preparation, ${ }^{14} \mathrm{C}$-leucine and metalaxyl) as prepared above were placed on a shaker at 100 oscillation/min under a fluorescent lamp providing $250 \mu \mathrm{E} \cdot \mathrm{m}^{-2} \cdot \mathrm{s}^{-1}$ photosynthetic photon flux density at the top of the flasks. A control blank with only distilled water was used for comparison. At the end of 30 and $60 \mathrm{~min}$ of incubation time, a 500- $\mu \mathrm{l}$ sample was collected from each flask with a micropipetter and placed in a $20-\mathrm{ml}$ vial. To each tube, $2 \mathrm{ml}$ of ice-cold trichloroacetic acid (TCA) (10 wt/vol) was added and the vials were left overnight at $4{ }^{\circ} \mathrm{C}$ in a refrigerator. The TCA-insoluble protein precipitates then were collected by filtering each sample through $2.1-\mathrm{cm}$ glass fiber filter disks. The filter disks were washed successively with $6 \mathrm{ml}$ ( 3 by $2 \mathrm{ml}$ ) of icecold TCA, $6 \mathrm{ml}$ ( 3 by $2 \mathrm{ml}$ ) of $80 \%$ ethanol, $2 \mathrm{ml}$ of acetone, and $4 \mathrm{ml}(2$ by $2 \mathrm{ml})$ of diethylether. The disks were dried, put into vials with $20 \mathrm{ml}$ of scintillation fluid, and radioassayed.

Counts per minute (CPM) of ${ }^{14} \mathrm{C}$ were measured and were converted to disintegration per minute (DPM) based on the counting efficiency of the liquid scintillation counter $(>97 \%)$. The results were converted to DPM/mg/chlorophyll and data was subjected to analysis of variance. There were three replications in an experiment and all experiments were conducted twice. The combined data was subject to analysis of variance and the means were compared using Duncan's multiple range test.

\section{RESULTS AND DISCUSSION}

Pepper growth assay. Metalaxyl and its $\mathrm{S}^{+}$isomer reduced the fresh weight of pepper compared with the isomer $\mathrm{R}^{-}$(Fig. 2). The difference was evident even at $0.1 \mathrm{ppm}$. At this lowest concentration, the average fresh weight of pepper seedlings treated with the control, $\mathrm{S}^{+}$, and $\mathrm{R}^{-}$was 600,425 , and $707 \mathrm{mg}$, respectively. Pepper plants treated with metalaxyl or the $\mathrm{S}^{+}$isomer had significantly lower fresh weights than control plants at all concentrations, whereas the $\mathrm{R}^{-}$caused lower weights than the controls only at $\geq 100 \mathrm{ppm}$.

The similarity in pepper weight reductions caused by metalaxyl and the $\mathrm{S}^{+}$at all concentrations indicates that $\mathrm{S}^{+}$isomer is the herbicidal component of the mixture. Another acylalanine fungicide, CGA 29212

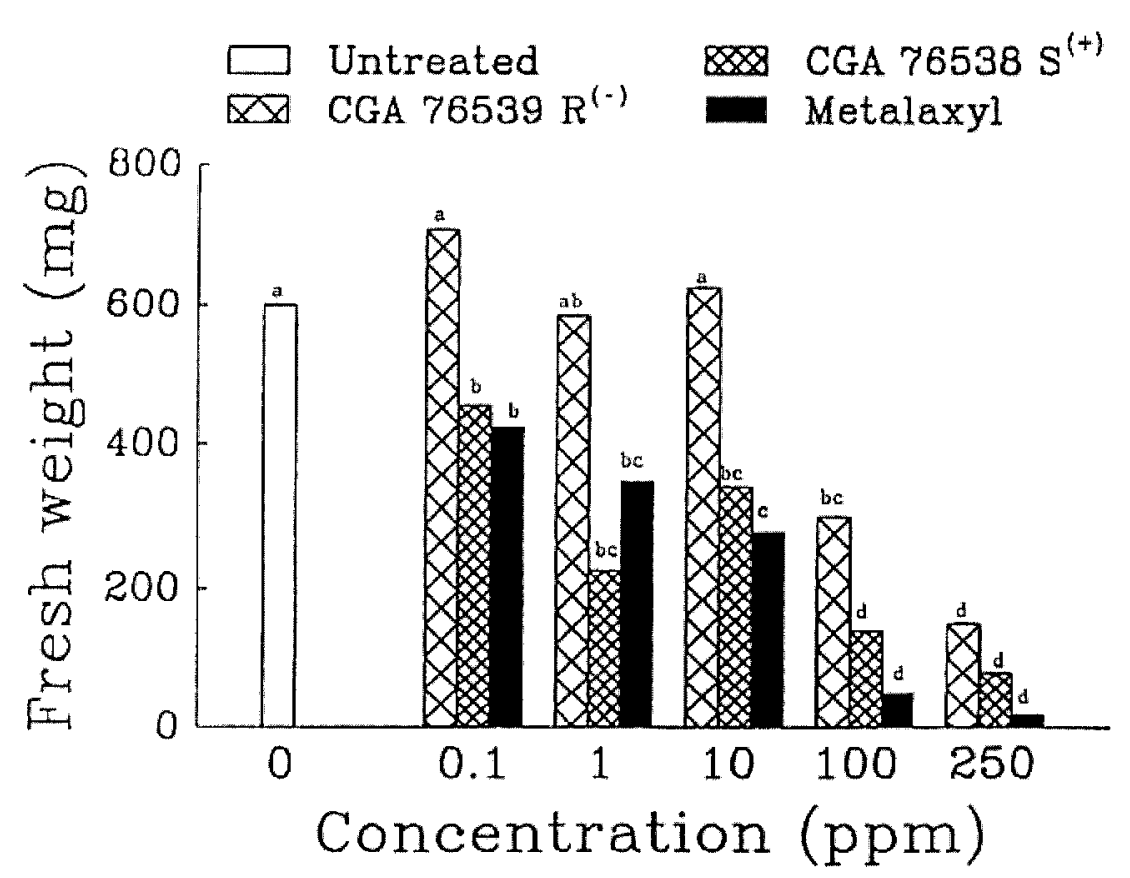

Fig. 2. Fresh weights of pepper plants treated with metalaxyl and its two optical isomers. Means followed by the same letter are not significantly different according to the $t$ test at 0.05 probability level. 
(methyl N-(2,6-dimethylphenyl)-N-chloroacetylalaninate), also is reported to be composed of two isomers that differ in their biological activity (11). In this study, the dextrotatory $\mathrm{S}^{-}$enantiomer had no fungicidal activity but was highly herbicidal, whereas the $\mathrm{R}^{-}$enantiomer has the opposite properties, with no herbicidal activity but highly active as a fungicide (11).
Citrus cellular assay. Preliminary experiments on the uptake of ${ }^{14} \mathrm{C}$-metalaxyl were conducted for up to $60 \mathrm{~min}$. The results showed that absorption increased steadily up to $30 \mathrm{~min}$ and there was no increase thereafter (data not presented). Two incubation periods ( 30 and $60 \mathrm{~min}$ ) were selected for this study because maximum uptake of metalaxyl by the cells oc-

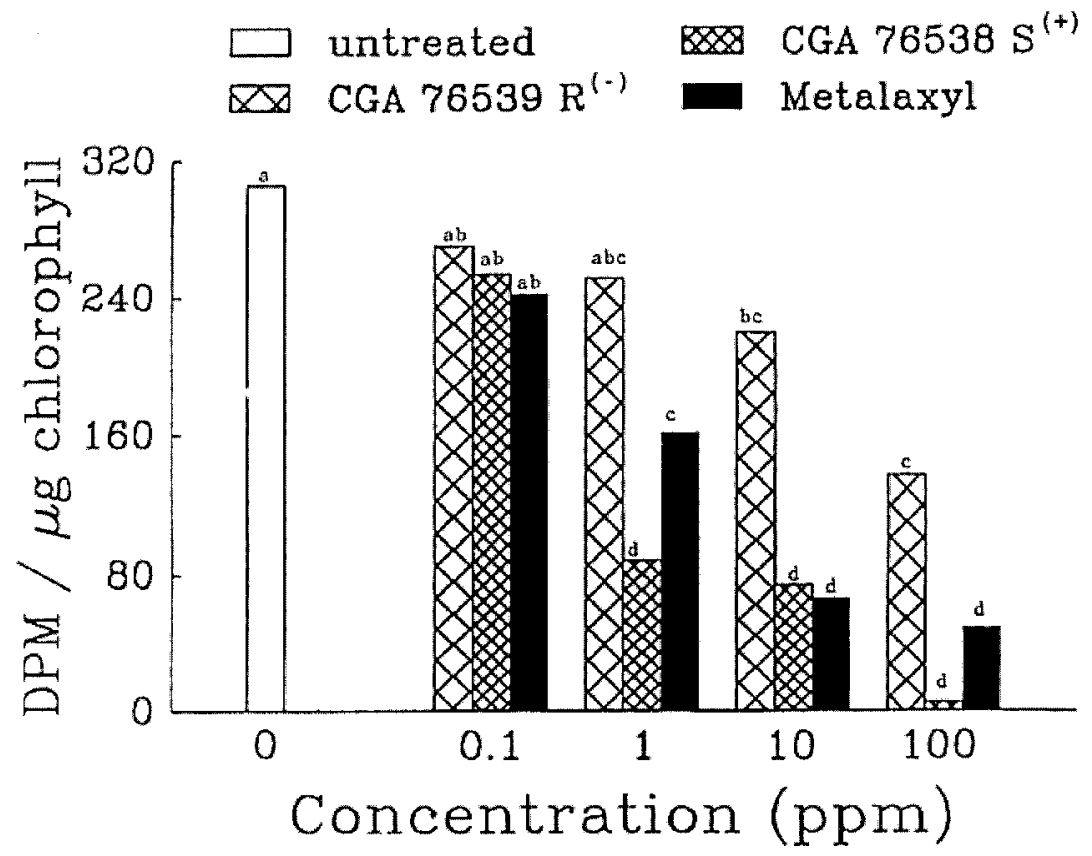

Fig. 3. Effect of metalaxyl and its optical isomers on ${ }^{14} \mathrm{C}$-leucine incorporation by mesophyll cells of citrus (expressed as disintegrations per minute [DPM] $\mu \mathrm{g}$ chlorophyll ${ }^{-1}$ ) incubated for $30 \mathrm{~min}$. Means followed by the same letter are not significantly different according to the least significant difference at $P=0.05$ probability level.

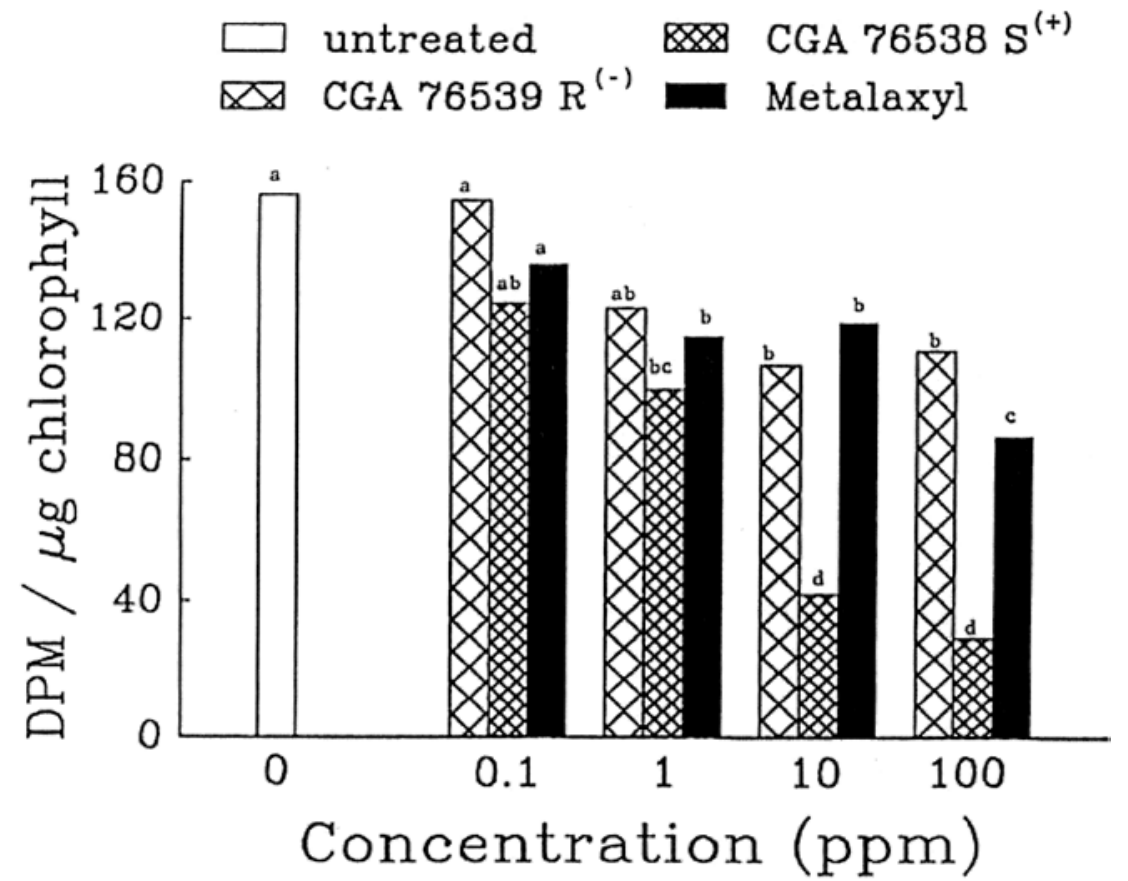

Fig. 4. Effect of metalaxyl and its optical isomers on ${ }^{14} \mathrm{C}$-leucine incorporation by mesophyll cells of citrus (expressed as disintegrations per minute [DPM] $\mu \mathrm{g}$ chlorophyll ${ }^{-1}$ ) incubated for $60 \mathrm{~min}$. Means followed by the same letter are not significantly different according to the least significant difference test at $P=0.05$ probability level.

curred over $30 \mathrm{~min}$. At $60 \mathrm{~min}$ of incubation, the untreated cells incorporated almost twice the ${ }^{14} \mathrm{C}$-leucine compared with the 30-min period (Figs. 3 and 4). There also was an increase in the absorption of ${ }^{14} \mathrm{C}$-leucine in all the treatments in the 60 min incubation.

After $30 \mathrm{~min}, 0.1 \mathrm{ppm}$ of metalaxyl and its isomers had no effect on incorporation of ${ }^{14} \mathrm{C}$-leucine by cells compared with the control (Fig. 3). At $1.0 \mathrm{ppm}$, metalaxyl and the $\mathrm{S}^{+}$isomer significantly reduced the incorporation of ${ }^{14} \mathrm{C}_{\text {-leucine by cells com- }}$ pared with the control. The $\mathrm{R}^{-}$isomer, however, had no ${ }^{14} \mathrm{C}$-leucine incorporation at $1.0 \mathrm{ppm}$. At $10 \mathrm{ppm}$, all three treatments reduced ${ }^{14} \mathrm{C}$-leucine incorporation relative to the control, but metalaxyl and the $\mathrm{R}^{-}$ isomer reduced incorporation more than the $\mathrm{S}^{+}$isomer. At $30 \mathrm{~min}$ of incubation, the maximum reduction of ${ }^{14} \mathrm{C}$-leucine incorporation by the $\mathrm{R}^{-}$isomer (at $100 \mathrm{ppm}$ ) was only $29 \%$ relative to the untreated control; whereas, for metalaxyl and the $\mathrm{S}^{+}$ isomer, ${ }^{14} \mathrm{C}$-leucine incorporation was 46 and $81 \%$ lower than the control, respectively.

Inhibition of ${ }^{14} \mathrm{C}$-leucine uptake in cells at $60 \mathrm{~min}$ was greater than the control when treated with metalaxyl and the $\mathrm{S}^{+}$ isomer at 1, 10, and $100 \mathrm{ppm}$. At the highest concentration tested (100 ppm), the $\mathrm{R}^{-}$ isomer inhibited ${ }^{14} \mathrm{C}$-leucine incorporation by $65 \%$; whereas, for metalaxyl and the $\mathrm{S}^{-}$ isomer, inhibition was greater. The inhibition of ${ }^{14} \mathrm{C}$-leucine incorporation by metalaxyl and the $\mathrm{S}^{+}$isomer appeared to be time dependent. At $30 \mathrm{~min}$, the inhibition at $1.0 \mathrm{ppm}$ by metalaxyl was $27 \%$ and, by the $\mathrm{S}^{+}$isomer, $36 \%$; whereas, at $60 \mathrm{~min}$, it increased to 47 and $61 \%$, respectively. For the $\mathrm{R}^{-}$isomer, inhibition percentages in the 30- and 60-min experiments were similar (21 and 18\%). Similar effects of incubation time on inhibition of incorporation of radioactive precursors into protein by cultured cells were observed for 2-chloroN,N-di-2-propenylacetamide (CDAA; 2) and S-ethyl dipropylcarbamothioate (EPTC; 5). This could be because of a delay in absorption or subcellular transport, a delay in the induction of the inhibition, or because the chemicals were inhibiting a metabolic site that supplied an essential factor for protein synthesis rather than affecting it directly. Based on our data, it is not possible to determine which of these factors may be responsible for the delayed inhibition of ${ }^{14} \mathrm{C}$-leucine incorporation.

The incorporation of ${ }^{14} \mathrm{C}$-leucine by cells appears to be a sensitive assay to identify the herbicidal effect of metalaxyl and its isomers. Photosynthesis also was examined by determining the fixation of ${ }^{14} \mathrm{CO}_{2}$ from $\mathrm{NaH}^{14} \mathrm{CO}_{3}$ by citrus cells (data not presented). However, photosynthesis was not significantly inhibited by treatment concentrations up to $100 \mathrm{ppm}$ after $60 \mathrm{~min}$ of incubation. This suggests that metalaxyl, 
like the other acylalanines, does not have a direct effect on $\mathrm{CO}_{2}$ fixation. On the other hand, the inhibition of ${ }^{14} \mathrm{C}$-leucine incorporation by metalaxyl is similar to the effect produced by other acylalanines. For example, chloroacetamide herbicides, including alachlor and CDAA, have been reported to strongly inhibit protein synthesis in various systems $(2,12)$.

The results presented in this report indicate that the herbicidal effect of the fungicide metalaxyl is caused by the $\mathrm{S}^{+}$isomer. This clearly is shown by data from the pepper growth assay and ${ }^{14} \mathrm{C}$-leucine incorporation. Our results also further confirm previous findings (4) that, for nonphotosynthetic inhibitors, the ${ }^{14} \mathrm{C}$-leucine incorporation assay can be used to identify toxicity of chemicals at the cellular level.

The $\mathrm{S}^{+}$isomer was removed from the formulation of metalaxyl and has enabled the continued use of this important fungicide for the control of citrus root and foot rot.

\section{ACKNOWLEDGMENTS}

We thank CIBA-GEIGY Corporation for providing financial support and chemicals for this project.

\section{LITERATURE CITED}

1. Arnon, D. I. 1949. Copper enzymes in isolated chloroplasts. Polyphenoloxidase in Beta vulgaris L. Plant Physiol. 24:1-7.

2. Ashton, F. M., de Villiers, O. T., Glenn, R. K., and Duke, W. B. 1977. Localization of metabolic sites of action of herbicides. Pestic. Biochem. Physiol. 7:122-141.

3. Davis, R. M. 1982. Control of Phytophthora root and foot rot of citrus with systemic fungicides metalaxyl and phosethyl aluminum. Plant Dis. 66:218-220.

4. Egli, M. A., Low, D., White, K. R., and Howard, J. A. 1985 Effects of herbicides and herbicide analog on ${ }^{14} \mathrm{C}$-leucine incorporation by suspension-cultured Solanum nigrum cells. Pestic. Biochem. Physiol. 24:112-118.

5. Ezra, G., and Gressel, J. 1982. Rapid effects of a thiocarbamate herbicide and its dichloroacetamide protectant on macromolecular syntheses and glutathione levels in maize cell cultures. Pestic. Biochem. Physiol. 17:4854.

6. Farih, J. A., Menge, J. A., Tsao, P. H., and Ohr, H. D. 1981a. Metalaxyl and efosite aluminum for control of Phytophthora gummosis and root rot of citrus. Plant Dis. 65:654-657.

7. Farih, J. A., Tsao, P. H., and Menge, J. A. 1981b. In vitro effects of metalaxyl on growth, sporulation, and germination of Phytophthora parasitica and $P$. citrophthora. Plant Dis. 65:651-654.

8. Freund, R. F., and Littell, R. C. 1981. SAS for
Linear Models: A Guide to ANOVA and GLM Procedures. SAS Institute, Inc., Cary, NC.

9. Hatzios, K. K. 1982. Use of isolated leaf cells of Abutilon theophrasti to localize the action of two amino-triazinone herbicidal derivatives. Z. Naturforsch. 370:276-281.

10. Hoagland, D. R., and Arnon, D. I. 1950. The water culture method of growing plants without soil. Calif. Agric. Exp. Stn. Circ. pp. 347.

11. Huble, A., Kunz, W., Eckhardt, W., and Sturm E. 1983. The fungical activity of acyl anilines. Pages 1-10 in: Pesticide chemistry Human Welfare and Environment. P. Doyle and T. Fujita, eds. Pergamon Press, New York.

12. Mann, J. D., Jordan, L. S., and Day, B. E. 1965. A survey of herbicides for their effect upon protein synthesis. Plant Physiol. 40:840843.

13. Sandler, H. A., Timmer, L. W., Graham, J. H., and Zitko, S. E. 1989. Effect of fungicide applications on populations of Phytophthora parasitica and on feeder root densities and fruit yield of citrus trees. Plant Dis. 73:902906.

14. Singh, M., and Mersie, W. 1993. Metalaxyl toxicity to citrus with or without herbicides. Weed Technol. 7:511-514.

15. Timmer, L. W. 1979. Preventive and systemic activity of experimental fungicides against Phytophthora parasitica on citrus. Plant Dis. Rep. 63:324-327.

16. Vencill, W. K., ed. 2002. Herbicide Handbook, 8th ed. Weed Sci. Soc. Am. Lawrence, KS. 